Research Paper:

\title{
Sources of Anxiety and Satisfaction Level of the Mothers Whose Children Hospitalized for Acute Reasons
}

\author{
Dilek Küçük Alemdar ${ }^{1}$ id, Gamze Yılmaz $^{2 *}$ (i)
}

1. Department of Nursing, Faculty of Health Sciences, Giresun University, Giresun,Turkey.

2. Department of Nursing, Health High School, Agri İbrahim Çeçen University, Ağrl, Turkey.

\begin{tabular}{|c|c|}
\hline $\begin{array}{l}\text { Use your device to scan } \\
\text { and read the article online }\end{array}$ & dratton: KüçükAlemdar, D., \& Y1lmaz, Gamze., 2018. Sources of Anxiety and Satisfaction Level of the Mothers Whose Children \\
\hline 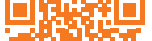 & Hospitalized for Acute Reasons. Journal of Client-Centered Nursing Care, 5(1), pp. 63-70. http://dx.doi.org/10.32598/jccnc.5.1.65 \\
\hline 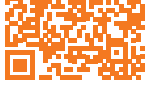 & doli http://dx.doi.org/10.32598/jcenc.5.1.65 \\
\hline
\end{tabular}

\section{(i) (8)}

Article info:

Received: 10 Aug 2018

Accepted: 25 Nov 2018

Published: 01 Feb 2019

Keywords:

Acute disease, Child, Mother, Anxiety, Satisfaction

\section{A B S T RA C T}

Background: To improve the quality of care in pediatric hospitals, health authorities and policymakers should evaluate the satisfaction of the clients. This study was conducted to determine the sources of anxiety and satisfaction of mothers whose children hospitalized for acute reasons.

Methods: It was a descriptive cross-sectional study. The study population comprised the mothers of 8-12 years old children who had been hospitalized in the pediatric department of a state hospital in Turkey because of acute reasons. Of them, a total of 341 mothers were recruited by convenience sampling method. The study data were collected by the mother-child information form, Parent Anxiety Resources Scale (PARS), Evaluation Form of Problems Faced by Parents of Children With an Acute Disease (EFPEPCAD) and PdsQL health care parental satisfaction scale. Then, the obtained data were analyzed by descriptive analysis procedures and t-test in SPSS.

Results: The Mean \pm SD age of the mothers was $32.28 \pm 7.24$ years. About $61.8 \%$ of the children had previous hospital experience, and $77.4 \%$ had been hospitalized because of the respiratory tract diseases. The Mean \pm SD score of the mothers from the PARS, EFPFPCAD, and PdsQL was $142.3 \pm 45.10,34.17 \pm 7.65$, and $58.60 \pm 28.87$, respectively. It was also determined that the PARS and EFPFPCAD scores of the working mothers and those whose children were previously hospitalized were significantly higher $(\mathrm{P}<0.05)$.

Conclusion: It was concluded that mothers had experienced a high level of intense anxiety and moderate satisfaction. To reduce the anxiety of the mothers and to identify the problems they face, the health care team should hold pre-admission programs, inform the parents about their children's disease, and make them aware of the hospital environment. By taking these measures, the satisfaction levels of the parents may increase.

\section{* Corresponding Author:}

Gamze Yılmaz, PhD.

Address: Department of Nursing, Health High School, Agri İbrahim Çeçen University, Ağrl, Turkey.

Tel: +90 (507) 8518226

E-mail: gamzeyilmaz@live.com 


\section{Highlights}

- Hospitalization of a child is a stressful experience for both the child and the family.

- The attitude of the health care team affects the entire hospital experience of the patient and his or her family.

- Parental opinions are important in evaluating the results of provided health care services.

- According to our study results, mothers experienced high levels of anxiety, moderate satisfaction, and moderate physical, psychosocial, and economic problems during the hospitalization of their children.

- To improve the quality of care in pediatric hospitals, the sources of anxiety, and satisfaction of the clients should be evaluated.

\section{Plain Language Summary}

The current study was conducted on 341 mothers to determine their sources of anxiety and satisfaction when their children are hospitalized for acute reasons. It was found that the mothers have experienced a high level of anxiety, moderate satisfaction, and moderate physical, psychosocial, and economic problems during their children's hospitalization. It was determined that the anxiety and problems faced by the working mothers and mothers whose children were previously hospitalized were significantly higher than not working mothers or mothers whose children were hospitalized for the first time. To improve the quality of care in pediatric hospitals, it is very important to evaluate the sources of anxiety and satisfaction of the mothers. It should be remembered that the role of health professionals is very important in mothers' positive hospital experience and care should be planned accordingly.

\section{Background}

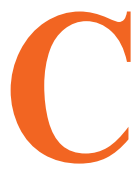

hildren ensure the continuity of families and give meaning to the life of their parents. On the other hand, the disease is one of the most common sources of stress that can happen to every growing child. The fact that the child is ill affects not only the child but also his or her family (Er 2006). Although outpatient follow-up and treatment are adequate in the majority of childhood diseases, some patients with high mortality and morbidity risks are hospitalized for close observation and or treatment (Polat, Mert \& Hallığlu 2006).

Admission in a hospital is a threat to family integrity. When the child needs to be hospitalized, significant changes occur in the lifestyle of the whole family. These changes cause all family members to experience fear, anxiety, stress, or crisis. Factors that cause this condition include having anxiety about the child's recovery, being unfamiliar with the hospital environment, finding themselves useless in the care of the child, and feeling guilty (Er 2006; Çavuşoğlu 2008). In such cases, the attitudes of the health care team significantly affect the entire hos- pital experience of the patient and his or her family (Öz $\&$ Sevil 2009).

By using family-centered care to hospitalized children, the patient and the family are considered a whole. Thus, providing a comfortable environment where the family can stay with the child guarantees that the families participate in the treatment (Er 2006; Çavuşoğlu 2008). Parents want to take good care of their children, to be in an environment of trust, to be able to rely on health staff and to be supported. They also want to be informed, to be hopeful, and their needs to be met during their stay in hospital (Hallström, Runeson \& Elander 2002). Meeting these emotional, humanistic, and physical needs greatly affect parental satisfaction (Ulus \& Kublay 2012).

Satisfaction is not only a subjective perception of the patient or patient relatives but also an essential indicator of health service quality (Engiz 1997). Parental satisfaction is defined as fulfilling the perceived positive expectations of the family in childcare (McPherson, Sachdeva \& Jefferson 2000). It is an important outcome demonstrating the organizational and clinical effectiveness of perceived quality care for families (Heyland et al. 2001). Parental satisfaction is a complex concept influenced by various factors and is one of the most important indica- 
tors of quality patient care (Y1lmaz 2001). Family satisfaction is as essential as the patient's care (Simons 2002).

Although satisfaction varies from one person to another, it is closely related to the appearance of the organization, the smiling face, the gentle approach, the quality of the materials used, the comfort offered to the patient, the cleanliness of the environment, and respect for the patient's privacy (Kinder \& Allen 2014). The nursing care given to a child, especially the communication with the parents and the environment in which care is given will have positive or negative effects on the family. The combination of all these factors creates parental satisfaction (Pherson, Sachdeva \& Jefferson 2000; Kinder \& Allen 2014).

Parental opinions are important in evaluating the results of provided health care services (Engiz 1997). When children are hospitalized, their mothers often accompany them (Arıkan, Tüfekçi \& Taştekin 2010). In our country, patient care focuses on the treatment of the child, and the needs of the family are usually ignored. Accordingly, this study was carried out to determine the sources of anxiety and satisfaction of mothers whose children had been hospitalized for acute reasons.

\section{Materials and Methods}

\section{Research design and sample}

This research was conducted as a descriptive crosssectional study to determine the sources of anxiety and satisfaction of mothers whose children got hospitalized for acute reasons. The study population was the mothers of 8-12 years old children who had been hospitalized because of acute reasons in the pediatric department of a state hospital in Turkey. The study sample consisted of the mothers of 341 children who agreed to participate in the study and met the inclusion criteria. The mothers were recruited by convenience sampling method.

Inclusion criteria: 1 . The child should be $8-12$ years old and be hospitalized because of an acute reason with no chronic diseases other than the diagnosis; 2 . Only the mother should stay with the child as a companion; 3 . The child and the mother should be in the hospital for 24 hours at least; 4 . The mother should be literate without any communication problems; and 5. The mother should agree to participate in the study.

\section{Data collection tools}

The data were collected by the mother-child information form, Parent Anxiety Resources Scale (PARS), Evaluation Form of Problems Faced by Parents of Children with Acute Disease (EFPFPCAD) and PdsQL health care parental satisfaction scale.

\section{Mother-child information form}

This form collects information such as the age, educational level, and working status of the mother, place of residence of the family, age, gender, and diagnosis of the child, previous hospitalization, and also the date of admission and discharge.

\section{Parent Anxiety Resources Scale}

The scale which was developed by Gönener and Pek (2009) and consisted of 57 items and 6 factors. The answers are scored with 4 options: think a lot (3), think slightly (2), think very little (1), and never think (0). The scores that can be obtained from the scale vary between 57 and 171. The higher the total scores, the higher would be the level of anxiety experienced by the individual.

\section{Evaluation Form of Problems Faced by Parents of Children with Acute Disease}

This form contains statements to determine the physical, social, and psychological factors that parents may experience during hospitalization. It consists of four parts that assess the affection status about hospitalization and illness process in parents whose children have to be treated as an inpatient because of acute health problem. The form contains a total of 26 questions and is scored based on a 4-point Likert-type scale. Answers to the level of affection for each substance are scored as no (0), slightly (1), medium (2), and much (3). The total score obtained varies between 0 and 78 . The high score indicates that the physical, psychosocial, and economic problems experienced by the parents during the hospitalization due to the child's acute illness have increased (Toka 2012).

\section{PedsQL Health Care Parental Satisfaction Scale}

This is a 25-question scale developed by James W. Varni in 1999. The questions in the scale aimed at measuring satisfaction with medical care services and psychosocial satisfaction. Psychosocial satisfaction is closely related to the emotional needs of the parents. The scale consists of 6 subscales: information, family participation, com- 
munication, technical skills, emotional needs, and general satisfaction (Varni, Quiggens \& Ayala 2000).

The statements in the PedsQL Health Care Satisfaction Scale are evaluated as never satisfied $=0$, sometimes satisfied $=25$, often satisfied $=50$, almost satisfied $=75$, and always satisfied $=100$ points. The scale's total score is obtained by dividing the sum of the scores obtained from each question by the number of questions ( 25 questions). The higher the scores, the more would be the level of satisfaction. PedsQL health care satisfaction scale was first adapted to Turkish, and its validity and reliability were confirmed by Ulus and Kublay (Ulus \& Kublay 2012).

\section{Data collection and procedure}

Before the research, the mothers were informed about the study, and its purpose by the researcher and their verbal and written informed consent was obtained. The data were collected by the questionnaires using answering- under-observation technique during face-to-face interviews. The implementation of all forms took approximately 15-20 minutes. The mother-child information form, PARS, and EFPFPCAD were completed at the end of the day of hospitalization and the PdsQL health care parental satisfaction scale was completed when the child was discharged from the hospital.

\section{Data analysis}

The data were analyzed in SPSS. Descriptive analysis (frequency, percentage, mean, standard deviation) and ttest were used to analyze the data. Statistical significance was set as $\mathrm{P}<0.05$.

\section{Results}

The Mean \pm SD age of the mothers was $32.28 \pm 7.24$ years. About, $66 \%$ passed the primary school. It was found that $90.6 \%$ of the mothers were not working and

Table 1. The sociodemographic characteristics of the mothers and the children

\begin{tabular}{|c|c|c|c|}
\hline \multicolumn{2}{|c|}{ Sociodemographic Characteristics } & \multirow{2}{*}{$\begin{array}{c}\mathbf{n} \\
167\end{array}$} & \multirow{2}{*}{$\begin{array}{l}\% \\
49\end{array}$} \\
\hline & Girl & & \\
\hline 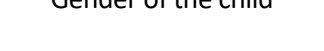 & Boy & 174 & 51 \\
\hline \multirow{3}{*}{$\begin{array}{l}\text { The education level of the } \\
\text { mother }\end{array}$} & Primary education & 225 & 66 \\
\hline & High school & 77 & 22.6 \\
\hline & University & 39 & 11.4 \\
\hline \multirow{2}{*}{ Occupation of the mother } & Working & 32 & 9.4 \\
\hline & Not working & 309 & 90.6 \\
\hline \multirow{2}{*}{ Place of residence } & Rural & 106 & 31.1 \\
\hline & Urban & 235 & 68.9 \\
\hline \multirow{3}{*}{$\begin{array}{l}\text { The reason for the child's } \\
\text { hospitalization }\end{array}$} & Respiratory tract infection & 264 & 77.4 \\
\hline & Gastrointestinal infection & 67 & 19.6 \\
\hline & Others & 10 & 3 \\
\hline \multirow{3}{*}{$\begin{array}{l}\text { Previous hospitalization of } \\
\text { the child }\end{array}$} & Yes & 211 & 61.8 \\
\hline & No & 130 & 38.2 \\
\hline & & 341 & 100.0 \\
\hline \multicolumn{2}{|c|}{ Sociodemographic Characteristics } & \multicolumn{2}{|c|}{ Mean \pm SD } \\
\hline \multicolumn{2}{|c|}{ Mother's age (y) } & \multicolumn{2}{|c|}{$32.28 \pm 7.24$} \\
\hline \multicolumn{2}{|c|}{ Child age (y) } & \multicolumn{2}{|c|}{$9.73 \pm 1.20$} \\
\hline \multicolumn{2}{|c|}{ Children's duration of hospital stay (d) } & \multicolumn{2}{|c|}{$3.02 \pm 2.56$} \\
\hline
\end{tabular}


Table 2. Distribution of the mean scores of PARS, EFPFPCAD, and PdsQL (N=341)

\begin{tabular}{cc}
\hline Scale & Mean \pm SD \\
\hline PARS & $142.3 \pm 45.10$ \\
EFPFPCAD & $34.17 \pm 7.65$ \\
PdsQL & $58.60 \pm 28.87$ \\
\hline
\end{tabular}

Table 3. PARS, EFPFPCAD, PdsQL scores according to the working status of mothers

\begin{tabular}{cccc}
\hline Scale & Working Mean \pm SD & $\begin{array}{c}\text { Not Working } \\
\text { Mean } \pm \text { SD }\end{array}$ & $\begin{array}{c}t \text { and } \\
\mathbf{P}\end{array}$ \\
\hline PARS & $150.6 \pm 41.25$ & $146.9 \pm 42.09$ & $\mathrm{t}=0.82$ \\
$\mathrm{P}<0.05$ \\
EFPFPCAD & $38.82 \pm 6.83$ & $35.03 \pm 7.14$ & $\mathrm{t}=1.82$ \\
PdsQL & $56.43 \pm 26.01$ & $58.27 \pm 27.53$ & $\mathrm{P}<0.05$ \\
\hline
\end{tabular}

$68.9 \%$ lived in the downtown. The Mean \pm SD age of the children was $9.73 \pm 1.20$ years, and $51 \%$ were male. Around $61.8 \%$ of the children had previous hospital admission, and $77.4 \%$ were hospitalized because of the respiratory tract disorders. The Mean $\pm \mathrm{SD}$ duration of hospital stay of the children was $3.02 \pm 2.56$ days (Table 1). Table 2 presents the distribution of the mothers' Mean \pm SD scores of PARS, EFPFPCAD, and PdsQL. It was found that the mothers' Mean \pm SD scores for PARS, EFPFPCAD, and PdsQL were 142.3 $\pm 45.10,34.17 \pm 7.65$, and $58.60 \pm 28.87$, respectively.

Table 3 compares the PARS, EFPFPCAD, and PdsQL scores according to the working status of the mothers. The PARS mean score of the working mothers was $150.6 \pm 41.25$, and it was $146.9 \pm 42.09$ for non-working mothers, and the difference was statistically significant
$(\mathrm{P}<0.05)$. It was found that the score of working mothers from EFPFPCAD was $38.82 \pm 6.83$, and there was a significant difference between working and non-working mothers $(\mathrm{P}<0.05)$. Mean \pm SD PdsQL score of the nonworking mothers was $58.27 \pm 27.53$.

Mean \pm SD PARS score of the mothers whose children were previously hospitalized was $150.6 \pm 41.25$, the EFPFPCAD Mean \pm SD score was $36.54 \pm 6.39$, and Mean \pm SD PdsQL score of the mothers whose children had not been hospitalized before was $59.58 \pm 27.65$. Therefore, a significant difference was found between the mean scores of PARS and EFPFPCAD of the mothers of children with and without hospitalization $(\mathrm{P}<0.05$, Table 4$)$.

Table 4. PARS, EFPFPCAD, PdsQL scores according to the child's previous hospitalization

\begin{tabular}{|c|c|c|c|}
\hline \multirow{2}{*}{ Scale } & \multicolumn{2}{|c|}{ Mean $\pm S D$} & \multirow{2}{*}{$\underset{P}{t \text { and }}$} \\
\hline & Previously Hospitalized & Not Previously Hospitalized & \\
\hline PARS & $149.5 \pm 43.02$ & $143.7 \pm 44.32$ & $\begin{array}{l}t=4.56 \\
P<0.05\end{array}$ \\
\hline EFPFPCAD & $36.54 \pm 6.39$ & $32.43 \pm 8.01$ & $\begin{array}{l}t=3.21 \\
P<0.05\end{array}$ \\
\hline PdsQL & $57.06 \pm 29.72$ & $59.58 \pm 27.65$ & $\begin{array}{l}t=1.05 \\
P>0.05\end{array}$ \\
\hline
\end{tabular}




\section{Discussion}

Hospitalization of a child is a stressful experience for both the child and the family (Curley, Hunsberger \& Sion 2013). Parents whose children are hospitalized experience fear and anxiety (Varni, Quiggens \& Ayala 2000). In our study, the PARS Mean \pm SD score obtained by the mothers was $142.3 \pm 45.10$ (Table 2). A total score of 171 from the PARS indicates that mothers are experiencing a high level of anxiety. In the study of Gönener and Pek (2009), it was found that the PARS Mean \pm SD score obtained by mothers was $158.1 \pm 14.4$, which is consistent with our study findings. In the same study, it was found that after the training given to mothers, they received a Mean \pm SD score of $17.6 \pm 6.3$.

It was concluded that the parents were worried about their children's hospitalization, and their anxiety decreased when they were trained. In another study conducted in our country, it was found that mothers did not share their concerns with nurses. The mothers complained that the nurses were busy, did not understand them, harshly treated mothers, and finally, the nurses did not solve their concerns (Oktay, 2004). It seems that minimizing the anxiety of children and their parents in the hospital environment is very important in terms of adaptation to care and treatment.

In our study, Mean \pm SD EFPFPCAD score of the mothers was $34.17 \pm 7.65$, indicating that the mothers' physical, psychosocial, and economic problems were moderate (Table 2). In Tokay's study (2012), it was found that Mean \pm SD EFPFPCAD score of the mothers was $32.03 \pm 9.33$, which is similar to our results. It is known that the mothers who stay in the hospital are mostly unable to meet their basic needs, such as sleep, bathing, and rest (Arıkan, Tüfekçi \& Taştekin, 2010). Meeting the needs of mothers in the hospital environment provides them spiritual support, and this will affect the child's recovery process, as the parent will always be with the child during the hospital stay (Taşdelen, 2006).

Nurses must be sensitive to the problems and needs of companions as well as patients to provide quality nursing care (Çavuşoğlu 2008; Erdim, Bozkurt \& İnal 2006). Therefore, the needs of mothers should be identified and supported. Psychological evaluation and support of the parents will also make them feel good physically. Satisfaction is accepted as an important indicator of health service quality (Engiz 1997). In our study, Mean \pm SD score of the mothers on the PdsQL scale was $58.60 \pm 28.87$, indicating that mothers have experienced moderate satisfaction (Table 2). In the study of Ulus and
Kublay (2012), when the satisfaction scores of the parents were examined, it was found that the overall satisfaction score was 62.55. In the study of Yildirım (2013), it was found that the mean scores of the PedsQL scale of the parents were 71.6 points in the experimental group and 31.7 points in the control group.

The health care satisfaction scores of the group who were trained about the disease of the child were significantly higher than that of the untrained group. In the study of Çamur (2017), it was found that the PedsQL scale total score mean of the mothers who participated in the hospitalized childcare and who were trained for the care activities of the children was higher than that in the control group. Erden et al. (2006) showed that information and communication affect general parental satisfaction. Similar results with our study were obtained in Moumtzoglou's (2000) parental satisfaction research. In his study, Myren-Manbeck (2001) found that meeting the needs of the family and the child affected their satisfaction. We believe that initiatives to increase parental satisfaction are very important for improving the quality of health care.

In the case of hospitalization of their children, essential sources of distress for families are feelings of being more responsible, deterioration of family members' work arrangements, less time for sleep, and other needs (Toka 2012). It was found that the mean scores of PARS and EFPFPCAD of the working mothers were higher than the non-working mothers, and the difference was significant $(\mathrm{P}<0.05$, Table 3$)$. This result may be because the working mothers are under more stress and responsibility and the disruption of the work order as a result of hospitalization. We think that having a supportive person who can perform the work that the mother has to do during hospitalization will affect the mother positively. In a study, contrary to our study findings, no statistically significant difference was found between the mean EFPFPCAD scores according to the occupation and working status of the mother (Toka 2012).

It was found that the PARS and EFPFPCAD mean scores of the mothers whose children have been previously hospitalized were higher than that of the mothers whose children had not been hospitalized before and the difference was statistically significant $(\mathrm{P}<0.05$, Table 4). However, in a similar study conducted in our country, no relationship was found between the child's previous hospitalization and parental satisfaction (Gönener \& Pek 2009). 
Consistent with our study findings, in the study of Toka (2012), it was found that the difference between the EFPFPCAD mean scores according to the previous hospitalization status was statistically significant. It was found that the mean scores of the parents whose children were once hospitalized were significantly higher than that of mothers whose children who had never been hospitalized before. Our study suggests that the experiences of the mothers whose children were previously hospitalized were negative, and thus, the mothers were also affected negatively. It should be remembe red that the role of health professionals is vital in mothers' positive hospital experience and care should be planned accordingly.

In sum, mothers experience a high level of anxiety, moderate satisfaction, and moderate physical, psychosocial, and economic problems during their children's hospitalization. To reduce the anxiety of the parents and identify the problems they face, the health care team should hold pre-admission programs and inform the parents about their children's disease and make them aware of the hospital environment. With these measures, the satisfaction levels of the parents may increase.

To improve the quality of care in pediatric hospitals, it is very important to evaluate the satisfaction of the clients. It is recommended that parental satisfaction be regularly evaluated by using parental satisfaction measurement tools. It is suggested that nurses be aware of the anxiety experienced by parents, identify the cause of anxiety, support them to solve this problem with their educator, consultant, and supportive roles, and make special arrangements and initiatives for the needs of the parents.

\section{Ethical Considerations}

\section{Compliance with ethical guidelines}

Ethical approval was received from the Ethics Committee of Ağrı İbrahim Çeçen University (approval number: 95531838-050.99). Before the data collection, the parents were informed about the research procedure, and their consent was taken. Also, they were allowed to withdraw from the research whenever they wanted. The information content of the obtained forms will be kept confidential. All the procedures that were performed in this study were according to the ethical standards of the institutional research committee and the 1964 Helsinki declaration and its later amendments or comparable ethical standards.

\section{Funding}

This research did not receive any specific grant from funding agencies in the public, commercial, or not-forprofit sectors.

\section{Authors' contributions}

Conceptualization and methodology: Dilek Küçük Alemdar; Investigation and writing-original draft: Dilek Küçük Alemdar, Gamze Y1lmaz; Writing review and editing and supervision: Gamze Y1lmaz.

\section{Conflict of interest}

The authors declared no conflict of interest.

\section{References}

Arıkan, D., Tüfekçi, FG., \& Taştekin, A., 2010. [Problems and expectations of hospital attendants and relationship with their problem solving levels of in pediatry clinics (Turkish)]. Atatürk Üniversitesi Hemşirelik Yüksekokulu Dergisi, 10(2), pp. 49-57.

Çamur, Z., 2017. [Hastanede yatan çocuğun bakımına ebeveyn katılımının ebeveyn memnuniyetine, ebeveyn ve çocuk anksiyetesine etkisi (Turkish)] [MSc. thesis]. Aydın: Adnan Menderes Üniversitesi Sağlık Bilimleri Enstitüsü.

Çavuşoğlu, H., 2008. [The effects of hospitalization on children and family (Turkish)]. Ankara: Sistem Ofset Basımevi.

Curley, MAQ., Hunsberger M., \& Sion, Kh., 2013. Psychometric evaluation of the Family-Centered Care Scale (FCCS) for pediatric acute care nursing. Nursing Research, 62(3), pp. 160-8. [DOI:10.1097/NNR.0b013e318286d64b] [PMID]

Engiz, O., 1997. [Patient satisfaction in healthcare Osman in Osman Hayran (Turkish)]. İstanbul: Nobel Tip Kitapevi.

Er, M., 2006. [Children, illness, parents and siblings (Turkish)] Çocuk Sağlığı ve Hastalıkları Dergisi, 49(1), pp. 155-68

Erden, A., et al., 2006. [Reorganization in day surgery nursing care for child patient (Turkish)]. Anestezi Dergisi, 14(3), pp. 1927.

Erdim, L., Bozkurt, G., \& İnal, S., 2006. [The research of affected situation of mothers whom children in hospital (Turkish)]. Atatürk Üniversitesi Hemşirelik Yüksekokulu Dergisi, 9(3), pp. 43-7.

Gönener, D., \& Pek, H., 2009. [Improvoment of “Parents Anxiety Sources Scale" under conditions of disease and hospitalization of school age children and influence over "Children Anxiety Resources" (Turkish)]. Gaziantep Tip Dergisi, 15(1), pp. 31-40.

Hallström, I., Runeson, I., \& Elander, G., 2002. Observed parental needs during their child's hospitalization. Journal of Pediatric 
Nursing, 17(2), pp. 140-8. [DOI:10.1053/jpdn.2002.123020] [PMID]

Heyland, D. K., Tranmer, J. E. \& Kingston General Hospital ICU Research Working Group, 2001. Measuring family satisfaction with care in the intensive care unit: the development of a questionnaire and preliminary results. Journal of Critical Care, 16(4), pp. 142-9. [DOI:10.1053/jcrc.2001.30163] [PMID]

Kinder, F. D. \& Allen, L. R., 2014. Parents' perception of satisfaction with care from pediatric nurse practitioners instrument. Journal of Pediatric Health Care, 28(2), pp. 128-35. [DOI:10.1016/j.pedhc.2012.12.009] [PMID]

McPherson, M. L., Sachdeva, R. C. \& Jefferson, L. S., 2000. Development of a survey to measure parent satisfaction in a pediatric intensive care unit. Critical Care Medicine, 28(8), pp. 300913. [DOI:10.1097/00003246-200008000-00055] [PMID]

Moumtzoglou, A., et al., 2000. Development and application of a questionnaire for assessing parent satisfaction with care. International Journal for Quality in Health Care, 12(4), pp. 331-7. [DOI:10.1093/intqhe/12.4.331] [PMID]

Myren-Manbeck, L.K., 2001. Staff support of parents in the pediatric intensive care unit: What are we doing and is it what parents want? [PhD. dissertation]. Kingston: University of Rhode Island.

Oktay, H., 2004. [Examination of the care given in the pediatric wards of a university hospital in terms of family-centered care and determination of maternal views (Turkish)] [MSc. thesis]. Ankara: Hacettepe Üniversitesi Sağlık Bilimleri Enstitüsü.

Öz, N., \& Sevil, Ü,. 2009. [Investigation of the expectation of the parents of the patients treated in pediatrics clinic from nursing services (Turkish)]. International Congress on Performance and Quality in Health Proceedings. 19-21 March 2009, Antalya, Turkey.

Pherson, M. L., Sachdeva, R. C., \& Jefferson, L. S., 2000. Development of survey to measure parent satisfaction in a pediatric intensive care unit. Ciritical Care Medicine, 28(8), pp. 3009-13. [DOI:10.1097/00003246-200008000-00055] [PMID]

Polat, S., Mert, E., \& Hallıoglu, O., 2006. [Characteristics of the pediatric patients hospitalized in secondary health care facilities (Turkish)]. Stimulated Emission Depletion Microscopy, 15(9), pp. 164-68.

Simons, J., 2002. Parents' support and satisfaction with their child's postoperative care. British Journal of Nursing, 11(22), pp. 1442-9. [DOI:10.12968/bjon.2002.11.22.10955] [PMID]

Taşdelen, M., 2006. [Determination of the making level of the hospitalized childrenís parentsí needs (Turkish)] [MSc. Master thesis]. Afyon: Afyonkarahisar Kocatepe Üniversitesi Sağlık Bilimleri Enstitüsü.

Toka, KC, 2012. [Akut hastalıklı çocuklarda ebeveynlerin sorunları ve etkili faktörlerin değerlendirilmesi (Turkish)] [master dissertation]. İstanbul: İstanbul Bilim Üniversitesi Sağllk Bilimleri Enstitüsü.

Ulus, B., \& Kublay, G., 2012. [Turkssh adaptation of the PEDSQL health care parent satisfaction scale (Turkish)]. Acıbadem Üniversitesi Sağlık Bilimleri Dergisi, 3(1), pp. 44-50.

Varni, J. W., Quiggens, D. J. L., \& Ayala G. X., 2000. Development of the pediatric hematology/oncology parent satisfac- tion survey. Children's Health Care, 29(4), pp. 243-55. [DOI:10.1207/S15326888CHC2904_2]

Yıldırım, Z., 2013. [The affect of education, provided to the parents of children diagnosed as lower respiratory tract infections, on family satisfaction (Turkish)] [MSc. thesis] İstanbul: Marmara Üniversitesi Sağlık Bilimleri Enstitüsü.

Y1lmaz, M., 2001. [Patient satisfaction: A criteria of health care quality (Turkish)]. Hemşirelik Yüksekokulu Dergisi, 5(2), pp. 69-74. 